\title{
Preferensi Pemilih Muslim Milenial pada Pemilihan Presiden-Wakil Presiden 2019
}

\author{
Hasse Jubba, ${ }^{1 *}$ Suparto Iribaram, ${ }^{2}$ Mustaqim Pabbajah, ${ }^{3}$ Misbah Zulfa Elizabeth ${ }^{4}$ \\ ${ }^{1}$ Universitas Muhammadiyah Yogyakarta, ${ }^{2}$ Institut Agama Islam Negeri Fattahul \\ Muluk Jayapura Papua, ${ }^{3}$ Universitas Teknologi Yogyakarta, ${ }^{4}$ Universitas Islam Negeri \\ Walisongo Semarang - Indonesia
}

\begin{abstract}
This paper discusses the issue of the tendency to vote of millennial Muslim voters in presidentialvice presidential elections 2019. This issue is answered through three questions. Applying mixmethods of quantitative and qualitative, the data was obtained through surveys and interviews as well as literature studies. The results were analyzed using a descriptive-analytical analysis. These results of this research show three important things. First, millennial Muslim voters in the presidential-vice presidential election 2019 tend to choose civilians as potential leaders. Civilians are considered capable of overcoming problems and can advance Indonesia in the future. Second, there are variations in the reasons for voters voting their candidates. In addition to performance factors, firmness and competency factors are the drivers for voters to make choices regarding contending candidates. Third, differences in political choices have an impact on polarization among Muslim communities. Different choices lead to new groupings in Muslim societies and even tend to emerge hates and dislikes from each other.
\end{abstract}

Tulisan ini membahas tentang kecenderungan memilih bagi pemilih Muslim milenial pada Pemilihan Presiden-Wakil Presiden 2019. Dengan menggunakan mix-method kuantitatif dan kualitatif, data diperoleh melalui survey, observasi, wawancara dan studi literature. Data yang diperoleh diolah dengan menggunakan analisis deskriptif-analitis. Hasil kajian ini menunjukkan tiga hal penting. Pertama, pemilih Muslim milenial pada pemilihan presiden-wakil presiden 2019 cenderung memilih kalangan sipil sebagai calon pemimpin. Sipil dianggap mampu mengatasi persoalan dan dapat memajukan Indonesia di masa depan. Kedua, terdapat variasi alasan pemilih menentukan pilihannya terhadap calon atau kandidat. Selain faktor kinerja, faktor ketegasan dan kompetensi menjadi faktor yang mendorong pemilih menentukan pilihannya. Ketiga, perbedaan pilihan politik berdampak pada terjadinya polarisasi di kalangan masyarakat khususnya Muslim. Pilihan yang berbeda mendorong terjadinya pengelompokan baru dalam masyarakat, bahkan cenderung muncul sikap saling membenci di antara mereka.

Keywords: Islam; politics; Muslim voters; polarization; rational choice

*Korespondensi Penulis: Hasse Jubba (hasse@umy.ac.id)). Program Studi S3 Politik Islam-Ilmu Politik, Universitas Muhammadiyah Yogyakarta, Jl. Brawijaya, Geblagan, Tamantirto, Kec. Kasihan, Bantul, Daerah Istimewa Yogyakarta 55183. 


\section{Pendahuluan}

Keterpilihan Joko Widodo-Ma'ruf Amin pada pemilihan presiden (pilpres) 2019 telah diprediksi oleh banyak kalangan jauh hari sebelumnya. Beberapa survei merilis tingkat elektabilitas masing-masing calon pemimpin bangsa. Survei yang dilakukan oleh Kompas 22 Februari-5 Maret 2019 misalnya menunjukkan elektabilitas Joko Widodo-Ma'ruf Amin (Paslon 01) pada angka 49,2 \%, sedangkan pasangan Prabowo SubiantoSandiaga Uno (Paslon 02) pada angka 37,4 \%. Bahkan, tingkat elektabilitas Paslon 01 pada Oktober 2018 menunjuk angka 52,6\% dan Paslon 02 pada angka 32,7\%. Lembaga survei lain, Lembaga Survei Indoensia (LSI), juga melansir tingkat elektabilitas masing-masing Paslon melalui survei yang dilansir pada Maret 2019. Paslon 01 berada pada angka 58,7 \% dan Paslon 02 sebesar 30,9\%. Saiful Mujani Research and Consulting (SMCR) juga mengelurkan hasil survei yang menunjukkan Paslon 01 pada tingkat elektabilitas sebesar 54,9 \% dan Paslon 02 sebesar 32,1 \%. Selain disebabkan oleh posisi salah satu calon presiden yang masih aktif sebagai presiden RI, komposisi pasangan juga menjadi faktor penting yang dianggap mempengaruhi sikap pemilih untuk menjatuhkan pilihannya pada pasangan calon (Paslon). Komposisi pasangan calon yang bertarung pada pemilihan presiden-wakil presiden 2019 hanya dua, yaitu sipil-sipil dan militer-sipil.

Pada periode September 2018-Februari 2019, penulis juga melakukan survei di kalangan mahasiswa untuk melihat kecenderungan pilihan mereka terhadap calon presiden-wakil presiden. Survei ini melibatkan 208 responden. Dari responden tersebut, sebanyak 129 responden memilih pasangan 01 atau 62,01 \%. Hasil ini me- rupakan akumulasi dari kriteria Paslon sipil sebanyak 58 responden dan agamawan sebanyak 71 responden. Adapun Paslon 02 dipilih oleh 79 responden atau 37,98 \%. Survei ini memiliki kecenderungan yang sama dengan hasil beberapa survei yang telah ditampilkan di atas. Kecenderungan pilihan di kalangan muda Islam (milenial) ini memberikan gambaran bahwa mereka memiliki perhatian yang besar atas sosok pemimpin bangsa. Hal ini sekaligus menunjukkan adanya dinamika dan perbedaan pilihan yang dilatarbelakangi oleh perbedaan pertimbangan dan kepentingan pada masing-masing pemilih.

Studi mengenai alasan pemilih pada pemilihan seperti pemilihan presiden dan pemilihan legislatif telah banyak dilakukan oleh para ahli. Secara umum, mereka melihat tiga aspek mengenai alasan pemilih dalam menentukan pilihannya. Pertama, atas dasar ketokohan yang tentu saja tidak lagi berdasarkan kesamaan identitas primordial seperti agama dan etnis (Yoelvan Negong 2018). Faktor ketokohan ini menjadi salah satu alasan pemilih mendukung atau memilih pemimpin (Hendryadi 2014). Ketokohan ini tidak hanya terkait dengan charisma dan integritas (Ardianti 2018), tetapi juga popularitas (Adela 2012; Suardi 2017) seseorang. Kedua, studi-studi yang melihat alasan memilih karena visi dan misi kepemimpinan yang akan dilaksanakan oleh calon pemimpin (Agustina 2018; Azmi 2014; Hamidi 2010). Seseorang yang memiliki visi dan misi yang jelas akan dengan mudah menjalankan kepemimpinannya. Ketiga, studi yang melihat kecenderungan pilihan yang didasarkan pada kompetensi pemimpin (Hendryadi 2014; Mohtar 2005; Sasmita dan Raihan 2014) yang dianggap akan mampu membawa perubahan signifikan ke 
arah yang lebih baik dan mampu menjawab tantangan di masa depan. Studi-studi tersebut belum melihat secara tegas mengenai alasan kinerja dan sikap seorang calon yang menyebabkannya dipilih oleh publik. Oleh karena itu, studi ini akan menjelaskan alasan yang digunakan oleh publik pemilih dalam menentukan pilihannya.

Tulisan ini bertujuan untuk, pertama, mendeskripsikan kecenderungan memilih di kalangan Muslim milenial pada pemilihan presidenwakil presiden 2019; kedua, mengidentifikasi faktor-faktor yang mempengaruhi pilihan pemilih; dan ketiga, menganalisis dampak yang ditimbulkan oleh perbedaan tersebut. Tulisan ini disandarkan pada tiga asumsi. Pertama, pemilih Muslim milenial lebih cenderung memilih pasangan calon pemimpin yang disaksikan secara langsung, khususnya prestasi yang dihasilkan selama periode kepemimpinannya. Kedua, pemilih dalam menentukan pilihannya didorong oleh beberapa alasan seperti kinerja, sikap tegas, dan kompetensi calon pemimpin serta kebutuhan atas masa depan bangsa. Mereka dianggap mampu menyelesaikan persoalan-persoalan negara saat ini dan ke depan. Ketiga, perbedaan pilihan pada pemilihan presiden dan wakil presiden tidak hanya melahirkan perbedaan politik sebagai bagian dari proses demokrasi, tetapi juga telah memunculkan polarisasi di kalangan Muslim. Bahkan, polarisasi ini mengarah pada kebencian yang berkepanjangan karena diikuti oleh klaimklaim kebenaran masing-masing kelompok pendukung calon pemimpin.

Tulisan ini merupakan gabungan dari data lapangan dan data sekunder. Data lapangan diperoleh dari survei dan wawancara, sedangkan data sekunder diperoleh dari rilis survei beberapa lembaga survei di Indonesia. Penelitian ini dilakukan di Universitas Muhammadiyah Yogyakarta pada Oktober 2018-Februari 2019. Pengumpulan data dilakukan sebelum pemilihan presidenwakil presiden (17 April 2019) yang bertujuan untuk melihat sekaligus memprediksi serta membandingkan kecenderungan pemilih dengan berbagai survei yang dilakukan oleh beberapa lembaga di Indonesia. Pengumpulan data dilakukan dengan membagikan kuesioner kepada mahasiswa pada 4 (empat) program studi di tiga fakultas, yaitu: 1) Program Studi Ilmu Pemerintahan pada Fakultas Ilmu Sosial dan Ilmu Politik, 2) Program Studi International Program of Laws pada Fakultas Hukum, 3) Program Studi Ekonomi Syariah dan 4) Program Studi Pendidikan Agama Islam pada Fakultas Agama Islam. Mereka terdiri atas mahasiswa semester satu dan tiga yang dipilih secara acak.

Kuesioner dibagikan kepada mahasiswa secara acak. Kuesioner yang dibagikan sejumlah 250 dan kembali sebanyak 208 buah. Ada tiga pertanyaan pokok yang diajukan kepada responden, yaitu 1) indikator apa yang menunjukkan bahwa calon pemimpin nasional dianggap ideal untuk memimpin Indonesia (sipil dan militer), 2) unsur calon seperti apa (agamawannon agamawan) yang dipilih pada pemilihan presiden 2019, dan 3) alasan memilih pasangan calon pemimpin. Pada salah satu pertanyaan, penulis mengajukan pertanyaan terbuka yang harus dijawab. Jawaban dari mereka, penulis mengutipnya dalam tulisan sebagai data seperti halnya data yang diperoleh melalui wawancara langsung. Sebaran responden menurut daerah 
asal sangat beragam meliputi mulai dari Nanggroe Aceh Darussalam hingga Papua Barat. Mereka juga berasal dari latar belakang pendidikan yang berbeda; ada yang berasal dari Sekolah Menengah Atas (SMA), Madrasah Aliyah (MA), dan Pondok Pesantren. Dari aspek umur, mereka berumur antara 17-23 tahun. Di antara mereka, terdapat jawaban yang tidak menunjuk pada salah satu pasangan calon karena dianggap belum waktunya menentukan pilihan (rahasia). Pilihan yang diberikan pun beragam dan hampir merata pada tiga kategori besar, yaitu sipil, agamawan, dan militer. Kategori sipil dan agamawan pada penyajian data disatukan dengan pertimbangan bahwa agamawan juga termasuk kategori sipil.

Penyajian data dilakukan baik dalam bentuk chart maupun narasi berupa kutipan wawancara. Selain menggunakan kuesioner sebagai alat pengumpulan data, penulis juga melakukan wawancara kepada beberapa mahasiswa terkait dengan rasionalisasi pilihan pada pemilihan presiden 2019 yang dilakukan pada 12 November 2018 dan 14 Januari 2019. Informan yang diwawancarai juga merupakan responden yang dipilih. Pada lembar angket/kuesioner, juga dicantumkan beberapa pertanyaan terbuka mengenai alasan mereka menentukan pilihannya pada pemilihan presiden-wakil presiden tersebut. Pertanyaan yang diajukan adalah kelanjutan dari pertanyaan kuesioner. Oleh karena itu, tulisan ini menggunakan data kuantitatif dan kualitatif sebagai dasar analisis dengan menggunakan teori pilihan rasional. Asumsi dasar teori ini menekankan bahwa pilihan terhadap sesuatu disandarkan pada alasan-alasan yang rasional.

\section{Generasi Milenial dan Rasionalitas Memilih}

Momentum pemilihan umum seperti pemilihan presiden dan wakil presiden selalu menarik untuk dibahas. Momentum ini merupakan kesempatan untuk menentukan "nasib" suatu negara/bangsa untuk lima tahun mendatang. Hal ini memicu masyarakat untuk turut ramai memperbincangkan dan terlibat di dalamnya, termasuk memperbincangkan persoalan-persoalan politik, aktor-aktor politik, dan tantangantantangan politik. Perbincangan mengenai politik juga telah bergerak bukan hanya sebagai perbincangan kelompok tua, tetapi juga generasi milenial (Juditha dan Darmawan 2018). Generasi milenial adalah generasi yang menyukai teknologi dan mulai menyingkirkan cara konvensional seperti bertukar informasi (Andriyani, Zahra, dan Swasti 2017:2). Seiring berjalannya zaman dengan penyebaran informasi yang cepat, media sosial menjadi alat untuk menyampaikan suatu nilai dari pihak tertentu dalam jumlah yang masif di mana dalam konteks election media sosial sering dimanfaatkan tokoh politik sebagai sarana kampanye (Hong dan Nadler 2012; Howard 2005; Liebhart dan Bernhardt 2017; Rußmann 2012) yang selanjutnya menjadi alat bagi generasi milenial untuk mengenal tokoh politik lebih jauh. Faktor ketokohan ini kemudian menjadi salah satu alasan seseorang memilih calon pemimpin negaranya.

Hubungan antara perilaku pemilih dan partai politik dalam pemilihan umum telah menjadi kajian lama di negara-negara demokrasi. Bone dan Ranney dalam buku Politics and Voters (1963) misalnya mengemukakan bahwa orang 
Amerika Serikat dalam menentukan pilihannya dikarenakan oleh tiga alasan yakni ikatan emosional yang kuat dengan parpol (party identification), isu atau program atau visi dan misi yang dijanjikan (issue orientation), dan kualitas figur kandidat/calon (candidate orientation) tanpa dikaitkan dengan parpol atau isu/program yang diusung (Rudatyo 2009). Indikator-indikator tersebut menempatkan baik pemilih maupun partai politik memiliki hubungan yang tidak seragam. Pada satu sisi, dapat saja hubungan yang ada bersifat mutualis-simbiosis, tetapi pada kondisi tertentu dapat berupa hubungan yang separatis-konfiktual di sisi lain.

Penelitian mengenai alasan memilih generasi milenial Muslim telah dilakukan oleh banyak peneliti. Penelitian Cesur dan Naci yang dilakukan pada orang dewasa di Turki yang didominasi oleh Muslim dengan membandingkan preferensi dalam pemilihan menemukan bahwa pendidikan sekuler memiliki dampak kausal pada religiusitas dan preferensi pemilih untuk memilih partaipartai Islam (Cesur dan Mocan 2018). Pendidikan pada kaum perempuan Muslim di Turki cenderung memberikan dampak negatif terhadap pemilihan partai Islam. Terdapat perbedaan preferensi politik antara perempuan yang lahir tahun 1980-1985 (yang dianggap sebagai kelompok yang ketinggalan reformasi pendidikan) dengan mereka yang telah memiliki pendidikan di mana pada wanita yang lahir tahun 1980-1985 cenderung untuk memilih partai Islam. Pendidikan meningkatkan kecenderungan perempuan untuk mengidentifikasi diri mereka sebagai perempuan dengan gaya hidup modern. Sejalan dengan penelitian Cesur dan Naci yang dilakukan pada masyarakat mayoritas muslim, Kurzman dan Syed dalam artikelnya yang meneliti mengenai dominasi partai-partai Islam di negara-negara Islam menemukan bahwa di tempat mayoritas (Islam) kehadiran partai Islam tidak secara substansial meningkatkan jumlah suara pemilih mereka (Kurzman dan Naqvi 2010).

Selain itu, Nielsen dalam artikelnya yang menganalisis latar belakang munculnya suara muslim yang berbeda dalam perkembangan negara di Bengal Barat India menegaskan bahwa salah satu alasan pemilih muslim berpartisipasi atau memilih tokoh politik dalam pemilihan adalah dengan melihat latar belakang kesuksesan dalam pembangunan negara (Nielsen 2011). Sejalan dengan penelitian Nilsen, Beg dalam artikelnya menganalisis cara di mana selama beberapa tahun terakhir, partai-partai politik besar di negara bagian terbesar India di Uttar Pradesh mengkalibrasi kebijakan mereka dengan tujuan merayu pemilih Muslim (Beg 2017). Namun para pemilih Muslim sekarang tidak dapat dimenangkan oleh retorika kosong dan janji saat pemilu karena mereka juga ingin mendapat bagian atau manfaat langsung dari pembangunan. Berbeda dengan penelitian yang dilakukan di atas, penelitian Heathh, Gilles dan Sanjay mencatat bahwa dalam konteks pemilihan di India yang didominasi oleh masyarakat Hindu menunjukkan bahwa umat Islam cenderung memilih tokoh politik Muslim karena elemen strategis yang kuat untuk kalkulasi suara mereka, artinya atas kesamaan agama menjadi faktor penting dalam menentukan pilihan (Heath, Verniers, dan Kumar 2015). 
Selain itu, konsepsi Muslim tentang perwakilan politik sering ditekankan sebagai kelompok komunal sebagai unit dasar representasi (Heath et al. 2015) sehingga politisi Muslim dianggap lebih mewakili mereka (muslim) daripada yang dilakukan oleh orang Hindu. Pemilih juga menentukan pilihan karena adanya 'trauma' yang pernah dialami. Penelitian Heathh, Gilles dan Sanjay, Bareto, Dana dan Ocampo terhadap Muslim Amerika menunjukkan bahwa Muslim di sana mengalami tindakan diskriminatif dan diikuti oleh sentimen anti-Muslim sehingga mempengaruhi pilihan mereka (Gilles dan Sanjay, Ocampo, Dana, \& Barreto, 2018). Pengalaman sehari-hari Muslim Amerika yang ditandai oleh sentimen islamophobia dan diskriminasi, terutama pasca 11/9, mengakibatkan Muslim Amerika beralih ke komunitas mereka sendiri (Muslim) sebagai bentuk pengembangan rasa sosial yang positif.

Studi-studi di atas memperlihatkan bahwa kecenderungan seseorang memilih sesuatu dipengaruhi oleh banyak faktor. Salah satu faktor yang dilihat adalah keberhasilan seorang pemimpin selama kepemimpinannya. Faktor pendidikan dalam beberapa kasus di berbagai tempat juga berpengaruh terhadap pilihan pemilih. Demikian pula, faktor kesamaan identitas primordial seperti agama dan etnis juga berpengaruh. Bahkan, faktor kebencian terhadap salah satu kelompok, termasuk kelompok agama, juga mempengaruhi penentuan pilihan. Hal ini, misalnya, dapat dilihat pada islamophobia yang terjadi di berbagai tempat sehingga pemimpin Muslim tidak dipilih. Tulisan ini mendiskusikan beberapa hal penting, yaitu bagaimana kecen- derungan pemilih, faktor-faktor yang melatarbelakanginya, dan implikasi dari perbedaan pilihan tersebut. Pilihan pemilih selalu disandarkan pada rasionalisasi dan kalkulasi masingmasing. Rasionalitas pemilih meskipun sangat bersifat individual, namun paling tidak itulah yang menjadi dasar dalam menentukan pilihannya.

Pemilihan menimbulkan pertanyaan mengenai rasionalitas preferensi politik (van der Voort et al. 2018). Memahami preferensi seseorang dalam memilih dapat meningkatkan efektivitas promosi/kampanye yang dilakukan tokoh politik untuk mendulang suara. Untuk itu, teori pilihan rasional telah menjadi cara paradigmatik dalam menganalisis perilaku seseorang. Teori pilihan rasional adalah kerangka teori yang umum digunakan dalam berbagai ilmu sosial termasuk ekonomi, politik sains, dan sosiologi (Buskens 2015). Salah satu tokoh yang dianggap sebagai pendiri konsep pilihan rasional adalah John von Neumann, seorang ilmuwan matematika. Neumann memaparkan teori pilihan rasionalnya dalam bukunya Theory of Game of Strategy yang berkeyakinan bahwa konsep strategi dalam permainan merupakan konsep yang juga tergambar dalam kehidupan sehari-hari di mana setiap orang akan berhadapan dengan orang lain sebagai kompetitor dan berusaha mendapatkan hasil maksimal dari persaingan tersebut (Hafiz 2016). Selain Neuman, Boudon menyebutkan teori pilihan rasional menekankan pada pentingnya kata "rasional". Kata ini bermakna bahwa perilaku merupakan proses kognisi yang harus dapat dijelaskan. Dalam 
teori ini juga dijelaskan penggunaan istilah "utility maximizing approach" berupa konsep bahwa seseorang akan melakukan pilihan yang sangat menguntungkan bagi dirinya (Hafiz 2016).

Peran teori pilihan rasional dalam konteks politik menurut Oppenheimer dibangun di atas praduga dasar ganda yang menjelaskan perilaku individu adalah kunci untuk memahami fungsi lembaga-lembaga politik dan bahwa perilaku ini dapat dikumpulkan untuk memahami perilaku kelompok (Oppenheimer 2008). Penelitian yang dilakukan oleh Ganzach yang meneliti mengenai hubungan kecerdasan dan rasionalitas preferensi politik menegaskan bahwa baik kecerdasan maupun rasionalitas mencerminkan alasan yang baik (Ganzach 2018). Intelijensi adalah ukuran perbedaan individu dalam penalaran yang baik dan rasionalitas. Ia merupakan karakteristik penilaian dan keputusan yang didasarkan pada alasan yang baik. Dengan demikian, kecerdasan bisa terkait dengan preferensi rasional seperti yang dikemukakan oleh Steiner bahwa teori pilihan rasional dapat didasarkan pada motif moralitas dan altruism (Steiner 1990). Sementara itu, peneliti lain menjelaskan bahwa teori pilihan rasional adalah tentang bagaimana kita melihat diri kita sendiri dalam kaitannya dengan orang lain dan menggambarkan berbagai pilihan yang ditemukan oleh aktor, tidak hanya secara moral tetapi juga secara empiris (Monroe 2001).

\section{Kecenderungan Pilihan Generasi Milenial}

Kecenderungan responden seperti yang tergambar pada data di atas terpola pada unsur sipil, agamawan, dan militer. Kecenderungan pilihan tersebut dapat dilihat pada beberapa gambaran gambar berikut. Selain menunjukkan kecenderungan pada tipologi sipil-militer (Gambar 1), responden juga menunjukkan sikap inkonsisten karena meskipun memilih calon yang berlatar belakang militer, namun ketika ditawarkan pertanyaan langsung menyebut nama Paslon justru tidak memilih Paslon dari unsur militer (Gambar 2).

Pada Gambar 1, dapat dilihat kecenderungan pemilih memilih sipil sebagai calon pemimpinnya. Dari 208 responden, sebanyak 129 responden

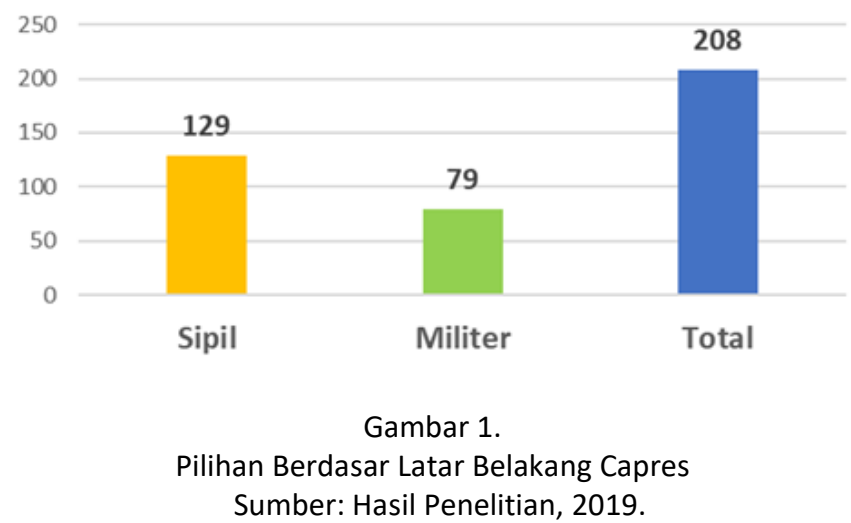

JSW (Jurnal Sosiologi Walisongo) - Volume 3, No. 2, 2019 
memilih sipil dan sebanyak 79 responden memilih unsur militer sebagai calon pemimpinnya. Pilihan terhadap Paslon sipil juga tidak lepas dari adanya unsur agamawan di dalamnya (Paslon 01). Ini sekaligus mewakili kecenderungan pemilih yang juga mempertimbangkan unsur agama sebagai preferensi memilih, khususnya bagi kelompok Muslim (Heath et al., 2015 dan Ocampo et al., 2018). Realitas bahwa masyarakat Indonesia adalah masyarakat religius dapat dibuktikan di sini. Bahkan, faktor agama sangat penting dan dianggap manjadi pertimbangan seseorang memilih calon pemimpinnya atas dasar kesamaan agama (Yoelvan Negong 2018). Mengingat kedua Paslon, baik calon presiden maupun wakil presiden adalah Muslim, maka selain faktor agama, faktor ketokohan juga menjadi factor penting lain yang dijadikan alasan pemilih memilih seorang calon pemimpinnya (Hendryadi 2014).

Mencermati data pada Gambar 2, tampak bahwa kecenderungan pemilih beragam dan tidak konsisten khususnya yang memilih sipil. Pada gambar tersebut misalnya dapat dilihat bahwa dari 129 responden yang memilih unsur sipil, ada sebanyak 79 responden yang justru memilih Prabowo Subianto-Sandiaga S. Uno (Paslon 02). Artinya, meskipun pemilih memilih unsur sipil misalnya, namun masih terdapat yang memilih Paslon yang berlatarbelakang militer. Demikian pula sebaliknya, pemilih yang cenderung memilih unsur militer karena dianggap memiliki sikap tegas, pada sikap berikutnya justru memilih Paslon yang tidak berlatarbelakang militer. Dari 79 responden yang memilih unsur militer, ada sebanyak 18 yang justru memilih Joko Widodo-Ma'ruf Amin (Paslon 01).

\section{Alasan Memilih pada Generasi Milenial}

Responden memilih preferensi yang berbedabeda dalam menentukan pilihannya terhadap pasangan calon pemimpin Indonesia. Mereka ada yang memilih berdasarkan pencapaian terhadap salah satu calon pemimpin, sehingga cenderung memilih Paslon 01. Responden yang lain justru memiliki kecenderungan yang berbeda memilih

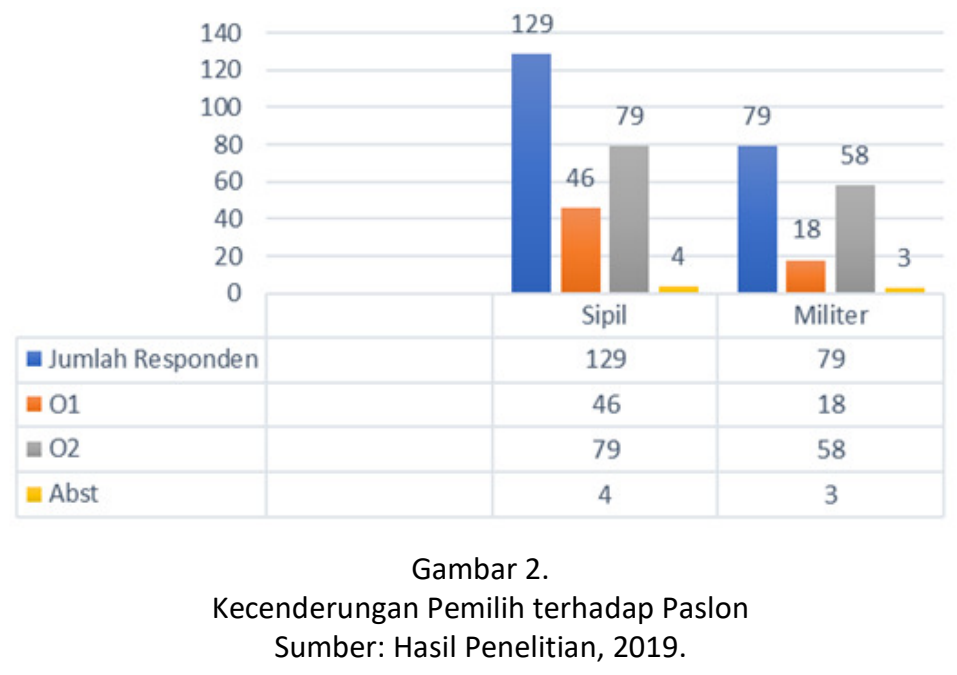

170

JSW (Jurnal Sosiologi Walisongo) - Volume 3, No. 2, 2019 
Paslon 02 dengan alasan sikap tegas karena berlatar-belakang militer. Perbedaan alasan memilih terhadap Paslon, salah satunya, diakibatkan oleh perbedaan kalkulasi untung-rugi masingmasing responden sehingga piliahnnya pun merujuk pada dua Paslon yang berkontestasi pada pemilihan presiden 2019 lalu. Ada tiga alasan yang melatarbelakangi mereka memilih salah satu Paslon pada pilpres 2019 lalu.

Pertama, alasan kinerja. Informan mendasarkan pilihannya pada pencapaian atau kinerja, artinya bukti yang telah ditunjukkan oleh seorang pemimpin (calon) selama ia memimpin. Kedua pasangan calon memiliki jejak kepemimpinan yang beragam. Baik Paslon 01 maupun Paslon 02 memiliki jejak yang Panjang. Pasangan calon 01 misalnya, Joko Widodo pernah menjabat sebagai Walikota di Solo, Gubernur DKI, dan terpilih menjadi Presiden RI pada 2009 lalu. Prabowo Subianto, seorang purnawirawan militer, lebih banyak karir kepemimpinannya dihabiskan di lingkungan militer pernah menduduki jabatan penting. Jabatan terakhir yang dijabat Prabowo Subianto adalah Komandan Jenderal (Danjen) Kopassus, sebuah jabatan yang sangat strategis di lingkungan militer. Pernyataan-pernyataan informan berikut memberikan gambaran bahwa kinerja merupakan salah satu alat ukur prestasi yang memancing memilih calon pemimpin.

MA (18), seorang informan asal DIY menyatakan memilih Paslon sipil karena kerja nyata yang telah dicapai selama kepemimpinannya. Ia menyatakan "beliau menerapkan prinsip kerja nyata seperti membangun infrasturktur jalan pada daerah-daerah terpencil". Ia juga mengatakan "pemimpin sipil mengetahui banyak ke- butuhan rakyat karena ia pernah mengalami hidup susah sehingga peduli kepada rakyat".

Pernyataan yang hampir sama dikemukakan oleh MIU (18) asal jawa Tengah. Ia mengemukakan:

"Sipil menurut saya akan lebih banyak dan bisa menampung aspirasi rakyat yang kemudian dapat diaplikasikan untuk memajukan Indonesia".

Kecenderungan memilih sipil juga diungkapkan oleh EY (19) asal Lampung: "Sipil lebih mengerti permasalahan yang ada pada masyarakat sehingga akan mengambil kebijakan yang tepat untuk menyelesaikan persoalan".

Pernyataan yang sama juga dikemukakan oleh WR (19) asal DIY:

"Sipil itu akan lebih mengetahui kebutuhan, bukan hanya satu golongan tertentu tetapi mengetahu kebutuhan golongan secara menyeluruh"

Ada pula yang menyatakan sikap sipil yang lebih netral ketika ia memimpin. Hal ini seperti yang diungkapkan oleh VP (17) asal Jawa Tengah:

"pemimpin yang berasal dari sipil (rakyat) akan mengerti keadaan rakyat dan apa yang dibutuhkan oleh rakyat karena ia pernah merasakan menjadi rakyat".

Kecenderungan pemilih seperti yang terungkap di atas lebih dilatarbelakangi oleh apa yang telah dilihat. Faktor kinerja seseorang menjadi perhatian utama. Secara kebetulan, salah satu Paslon semuanya berlatarbelakang sipil dan merupakan calon yang masih "berkuasa". Pemilih dengan mudah melihat kinerja Paslon tersebut, dibandingkan dengan Paslon lain yang memiliki latarbelakang berbeda khususnya militer yang 
hanya dapat dilihat pada periode ketika masih aktif di instansi kemiliteran. Artinya, prestasi Prabowo Subianto hanya terbatas pada instansi tertentu. Ini yang dapat dilihat secara langsung oleh pemilih. Apalagi, pemilih muslim milenial yang lahir setelah era kepemimpinan Prabowo telah berakhir di instansi militer. Di sinilah titik perbedaan yang sangat tampak bahwa Joko Widodo masih aktif sebagai Presiden dan pemilih menyaksikan secara langsung apa yang telah dikerjakannya. Hal ini berarti bahwa pemilih mendasarkan pilihannya pada prestasi nyata yang telah dicapai (Nielsen 2011) oleh seseorang.

Kedua, ketegasan sikap. Pemilih yang memiliki kecenderungan memilih Paslon yang berlatar belakang militer memiliki pandangan bahwa unsur ini memiliki ketegasan yang sangat dibutuhkan untuk kemajuan bangsa ini. Mengenai sikap tegas calon pemimpin, SPO (21) asal Jawa Timur mengatakan alasan memilih figur atas dasar sikap tegasnya. Ia mengatakan:

"Kita membutuhkan sosok pemimpin yang tegas untuk memakmurkan seluruh rakyat Indonesia dan menindak tegas oknumoknum yang menyeleweng".

Masih mengenai sikap tegas calon pemimpin, FS (18) asal Jawa Timur mengatakan; "Saya cenderung memilih sosok militer karena seseorang dari militer akan lebih tegas". Pengakuan yang sama juga disampaikan oleh ANA (18) asal Jakarta, ia mengatakan: "pemimpin yang berasal dari militer memiliki ketegasan dan kemampuan yang lebih baik".

Sikap yang sama juga ditunjukkan oleh NPA (19) asal Riau. Ia cenderung memilih Paslon dari kalangan militer karena memiliki ketegasan dan telah memiliki bakat kepemimpinan yang baik. Ia mengatakan:

"Pemimpin yang berlatarbelakang militer akan dapat memajukan Indonesia karena beliau telah dididik dengan tegas, disiplin, penuh tanggung jawab dan memiliki jiwa kepemimpinan"

Keempat informan di atas sepakat bahwa pemimpin yang memiliki ketegasan dapat memajukan Indonesia saat ini di masa mendatang. Sebab, pemimpin yang tegas akan dengan tegas pula menentukan kebijakan dan mengambil sikap dalam menyelesaikan persoalan yang ada. Oleh karena itu, mereka sangat mendukung pemimpin yang berlatarbelakang militer karena sangat identik dengan sikap tegas.

Ketiga, kompetisi global dan kebutuhan bangsa di masa depan. Negara-negara di dunia saat ini terlibat dalam persaingan global yang sangat ketat. Persaingan ini terjadi dari multidimensi seperti ekonomi, politik, sosial, dan pertahanan keamanan. Negeri-negara berkembang seperti Indonesia terus membekali diri untuk menghadapi kondisi ini. Kepemimpinan menjadi hal yang harus kuat karena tantangan bangsa di masa mendatang membutuhkan kepemimpinan yang kuat dan berani termasuk dalam pengambilan keputusan. Salah seorang dari mahasiswa yang menjadi informan, PNS (21) asal Yogyakarta, dengan terbuka mengatakan: "pemimpin dari unsur militer akan lebih tegas dalam mengambil kebijakan dan akan lebih tanggap dengan situasi kenegaraan". Pemimpin dari kalangan militer akan disegani oleh bangsa lain. SA (17) asal Lampung mengemukakan pendapatnya bahwa "Pemimpin yang berasal dari kemiliteran cenderung disegani bangsa lain". 
Kondisi Indonesia yang diterpa berbagai kasus korupsi membutuhkan sosok pemimpin yang berani untuk mengambil langkah tegas untuk mengatasi dan menyelesaikan persoalan tersebut. PDK(17) asal Nusa Tenggara Barat menyatakan:

"Persoalan korupsi yang meraja-lela di indonesia disebabkan oleh pemimpin yang kurang tegas. Sosok militer saya yakini mampu menyelesaikan persoalan-persoalan seperti korupsi ini".

Jika bangsa ini dipimpin oleh sosok yang berlatarbelakang militer, maka akan memberikan rasa aman. AW (18) asal Jawa Tengah, mengamini hal ini. Ia mengatakan: "jika kepemimpinan militer akan menciptakan rasa aman. Dalam sejarah Indonesia, kepemimpinan militer lebih baik untuk Indonesia."

Alasan pemilih menjatuhkan pilihannya pada salah satu Paslon karena kebutuhan bangsa memberikan penjelasan bahwa tantangan ke depan semakin kompleks sehingga membutuhkan pemimpin yang memiliki kompetensi yang dibutuhkan Indonesia. Saat ini, persaingan antarbangsa sangat ketat sehingga dibutuhkan pemimpin dan kepemimpinan yang sesuai dengan zaman. Pada konteks inilah, pemilih (para informan) melihat kecenderungan yang berbeda dan tipe yang ada pada setiap Paslon. Dengan kata lain, faktr kompetensi calon pemimpin menjadi daya tarik yang dapat mempengaruhi sikap pemilih. Kompetensi atau kemampuan seseorang dinilai mampu berbuat sesuatu lebih baik dari kondisi sebelumnya sehingga pemilih pun menjatuhkan pilihan pada dirinya (Hendryadi 2014; Mohtar 2005; Sasmita dan Raihan 2014).

Pilihan para informan seperti yang tergambar di atas bervariasi. Ada tiga kecenderungan yang ditunjukkan oleh mereka. Selain kinerja, alasan yang melatarbelakangi memilih calon pemimpin adalah sikap tegas dan kompetisi dunia yang menyebabkan tantangan bangsa Indonesia saat ini dan di masa yang akan datang semakin sulit. Ketiga alasan pilihan tersebut memiliki kesamaan dan perbedaan dengan apa yang telah dikemukakan oleh Bone dan Ranney (1981) dalam bukunya Politics and Voters, pada kasus pilihan orang Amerika Serikat dalam menentukan pilihannya. Ada tiga alasan yang mendasari pilihan mereka yaitu 1) ikatan emosional yang kuat dengan parpol (party identification), 2) isu atau program atau visi dan misi yang dijanjikan (issue orientation), dan 3) kualitas figur kandidat/calon (candidate orientation) tanpa dikaitkan dengan parpol atau isu/program yang diusung.

Kecenderungan ini sekaligus memberikan penjelasan bahwa pemilih muda Muslim telah memiliki pilihan berdasarkan penilaian dan rasionalisasi masing-masing terhadap calon pemimpin. Kinerja seorang pemimpin masih menjadi alasan utama informan menentukan pilihannya. Adapun alasan sikap tegas dan alasan kepentingan bangsa ke depan menjadi alasan lain informan yang juga memberikan gambaran secara umum kompleksitas persoalan yang dihadapi bangsa Indonesia. Pada tataran ini, rasionalisasi pemilih Muslim milenial tergambar dengan jelas ketika mereka memilih berdasarkan kalkulasi politik masing-masing (Fadli etal. 2015).

\section{Polarisasi Masyarakat Muslim}

Polarisasi dalam hal ideologi meruoakan sumber dari berbagai sumber konflik partisipasi dalam negara sebagai akibat penurunan kepercayaan terhadapa berbagai partai politik (Jones 
2015). Salah satu dampak langsung dari perbedaan kecenderungan pilihan pada pemilihan presiden-wakil presiden 2019 adalah polarisasi masyarakat. Polarisasi saat ini banyak terjadi pada level yang bersifat abstrak yang dapat dilihat pada pengelompokan masyarakat di media sosial seperti Facebook, Instagram, dan WhatsApp. Polarisasi secara virtual tidak bisa dielakkan mengingat kebutuhan masyarakat terhadap teknologi sangat tinggi. Perbincangan-perbincangan dalam media sosial sangat hangat dan terus mengiktui tren politik dalam negeri. Masyarakat pemilih bahkan dengan terbuka menunjukkan diri sebagai pendukung salah satu calon meskipun pemilihan presiden-wakil presiden belum dimulai. Masyarakat pun terpola berdasarkan pilihan masing-masing, yaitu pendukung Paslon 01 dan pendukung Paslon 02.

Polarisasi ini didorong oleh beberapa faktor. Pertama, kefanatikan terhadap salah satu figur atau calon. Hal ini dengan jelas dapat dilihat pada pemilih yang mendasarkan pilihannya pada unsur-unsur yang bernuansa etnis. Pemilih lebih cenderung memilih etnis yang sama dengannya. Bagi penulis, ini sangat rasional karena hal ini juga dilandasi oleh berbagai pertimbangan rasional. Meskipun ini akan mengentalkan politik identitas seperti yang banyak terjadi di era Reformasi saat ini. Kedua, sikap 'taklid' yang berlebihan terhadap salah satu tokoh pendukung. Dalam kontestasi Pilpres 2019, dapat dilihat adanya dukungan tokoh-tokoh nasional pada masing-masing kubu Paslon. Kehadiran tokoh tersebut, yang memiliki massa loyal, sangat berdampak pada arah pilihan pemilih. Ketiga, sikap antipati terhadap salah satu calon. Sikap seperti ini muncul akibat adanya persoalan yang lebih bersifat internal seseorang.
Misalnya, seseorang yang memiliki trauma atas pelakuan militer, tidak memilih Paslon yang berlatarbelakang militer. Demikian pula, seseorang yang memiliki memori kelam atas perlakukan sipil selama memimpin terhadapnya, tentu saja tidak akan memilih Paslon yang dimaksud.

Ketiga hal di atas dapat membawa masyarakat pada kondisi yang saling menafikan, artinya akan terbentuk arus yang saling berlawanan seperti siapa yang akan disertakan dan siapa yang akan ditolak (Haboddin 2012), artinya kelompok semakin terbatas dan selektif karena didasarkan pada prinsip siapa yang termasuk anggota kelompok dan siapa yang liyan. Kedua kelompok pendukung saling berkontestasi dalam banyak hal selain dalam perbedaan pilihan tadi. Mereka juga saling berkontestasi dalam mengajukan alasan-alasan yang digunakan untuk menjatuhkan Paslon atau kelompok pendukung yang lain. Bahkan, jika salah satu kelompok menjadi pemenang maka kelompok yang lain menjadi objek 'ejekan'. Hal ini berkaitan erat dengan persoalan munculnya "kebahagian" yang memunculkan tindakan jika para partai (calon) yang didukung menang dalam pemilihan umum mereka akan bahagia sedangkan jika tim lawan atau yang tidak didukung yang menang mereka tidak akan antusias dengan kinerja dan kebijakan yang diciptakan bahkan cendrung melakukan pengkritikan sebagai akibat kekalahan kandidat yang mereka pilih (Kinari et al. 2019).

Demikian pula, metode yang digunakan untuk 'menyerang' sangat beragam yang tidak hanya dalam bentuk sikap yang secara terbuka mendukung salah satu Paslon atau kandidat, tetapi juga secara massif melakukan propaganda melalui media sosial meskipun itu dilakukan dengan 
cara penyebaran berita-berita bohong (hoax). Berita-berita model ini banyak bermunculan dalam bentuk pemberitaan yang telah dimanipulasi karena sudah memiliki kepentingan yang jauh di luar konteks awalnya. Provokasi yang bersifat hoax juga muncul dalam bentuk gambar yang berisi ujaran kebencian dan fitnah yang disebarkan secara masif melalui WhatsApp (WA) group. Bahkan, banyak orang yang dikeluarkan dari WA grup karena memiliki sikap politik yang berbeda dengan kebanyakan orang di dalam sebuah grup.

Perbedaan pilihan ini juga membangkitkan memori pemetaan masyarakat di Indonesia yang masih diperdebatkan, khususnya polarisasi masyarakat Muslim menjadi abangan-santri, tradisionalis-modernis, dan sebagainya. Ini justru semakin membawa kalangan muslim ke ranah yang tidak menguntungkan karena terus berada pada kondisi perdebatan sengit di level internal, yang pada awalnya hanya dipicu oleh perbedaan pemahaman dan praktik keagamaan. Bahkan menurut Asyumardi Azra, hal seperti justru melahirkan 'politik aliran' pada masyarakat Indonesia khusunya di kalangan Muslim (Azra 2013) yang berakibat pada langgengnya sikap apriori terhadap keberadaan kelompok-kelompok sosial lain. Usaha pemolaan seperti ini juga didasarkan pada kecenderungan beberapa tokoh (tidak semua) kedua organisasi kemasyarakatan di Indonesia yang mendukung (meskipun tidak secara terbuka) salah satu Paslon pada pemilihan presiden-wakil presiden 2019 lalu.

Polarisasi masyarakat akibat perbedaan pilihan ini tidak hanya mengingkari perbedaan, tetapi juga telah membentuk bentuk kebencian baru yang berlangsung dalam waktu lama. Artinya, terbentuk kebencian yang berlangsung selama 5 (lima) tahun ke depan yang berlangsung hingga kontestasi pemilihan presiden-wakil presiden dilaksanakan lagi. Ada kecenderungan yang mengarah pada pemolaan pemilih secara organisatoris misalnya membelah Muhammadiyah dan Nahdlatul Ulama (NU) karena masing-masing mendukung Paslon yang berbeda. Bahkan, Polarisasi masyarakat dapat menyebabkan tingginya preferensi mereka terhadap pemilihan umum dan menyebabkan terjadinya tindakan yang merugikan orang lain yang diakibatkan oleh adanya perbedaan ideologi (Algara 2019). Di internal Muhammadiyah misalnya, terjadi perbedaan pilihan. Pada pemilihan 2014 lalu, dua tokoh penting Muhammadiyah memiliki sikap politik yang berbeda, Amin Rais memilih bergabung ke dalam partai di luar pendukung pemerintah sedangkan Syafii Ma'arif lebih cenderung ke pilihan lain. Hal ini berulang dan berlanjut pada pemilihan presiden-wakil presiden 2019. Hal yang sedikit berbeda di kalangan NU, yang memberikan dukungan terhadap salah satu calon. Perbedaan sikap politik seperti ini, yang terjadi misalnya antara pusat dan daerah (Sholikin 2018) dapat berakibat pada 'retaknya' kerjasama di berbagai level pemerintahan karena di dalamnya (DPRD) terdapat kubu pendukung yang memiliki sikap politikyang juga beragam.

\section{Kesimpulan}

Kecenderungan pemilih atau responden dalam menjatuhkan pilihannya pada sipil atau militer disebabkan oleh beberapa faktor. Ada tiga faktor yang menjadi pendorong perbedaan pilihan ini. Faktor kerja atau kinerja yang telah dicapai sebelumnya oleh calon pemimpin memiliki porsi yang lebih tinggi. Adapun sikap tegas ditempat- 
kan sebagai faktor penting berikutnya, mengingat kondisi bangsa saat ini membutuhkan pemimpin yang memiliki ketegasan termasuk dalam mengambil dan melaksanakan kebijakan-kebijakan. Tantangan bangsa yang semakin kompleks di masa mendatang dan tingginya persaingan antarnegara di dunia mendorong pemilih untuk mencari pemimpin yang memiliki kemampuan yang dapat mengatasi berbagai masalah yang ada selama ini dan berbagai persoalan yang akan datang. Pada pemilihan presiden-wakil presiden 2019, pemilih Muslim milenial tidak memiliki konsistensi dalam memilih. Di satu sisi, ada yang memilih Paslon sipil namun dengan tegas menyebut Paslon yang berlatar-belakang militer, demikian pula sebaliknya.

Adanya perbedaan alasan yang dikemukana oleh pemilih secara umum diakibatkan oleh rasionalisasi yang dibangun masing-masing terhadap kedua pasangan calon pemimpin negara. Bagi yang memilih pasangan calon 01 lebih tertarik menggunakan argumentasi seputar keberhasilan atau kinerja yang ditunjukkan oleh pilihannya. Pasangan calon 01 memang selama satu dekade ini terlibat langsung dalam pemerintahan sehingga karyanya masih dapat dilihat dan dinilai oleh pemilih muslim milenial. Pemilih yang lebih cenderung memilih pasangan calon 02 lebih didasarkan pada figur atau ketokohan calon yang dianggap memiliki sikap tegas dan akan mampu mengatasi berbagai persoalan termasuk tegas dalam menjalankan kebijakan pemerintahan. Selain itu, latarbelakang calon pemimpin (Paslon) juga mempengaruhi pemilih untuk menentukan pilihannya.
Perbedaan pilihan pada pemilihan presiden dan wakil presiden 2019, ternyata tidak berhenti pada pemilahan pilihan politik. Perbedaan tersebut menyisakan persoalan krusial, yaitu berlangsungnya kebencian di antara kelompok pendukung dalam banyak aspek kehidupan. Bahkan, kebencian ini dapat berlangsung selama lima tahun sampai pemilihan presiden-wakil presiden berikutnya. Kondisi ini misalnya, ditemukan pada berbagai media sosial adanya polarisasi di kalangan masyarakat Muslim yang terjadi secara nyata. Polarisasi ini sebagai dampak dari perbedaan pilihan kemudian berlanjut pada perdebatan yang tidak berujung sehingga melahirkan klaim kebenaran masing-masing kelompok. Rasionalisasi terhadap pilihan sangat kuat, seperti yang tercermin pada uraian di atas, namun tidak diikuti oleh sikap rasional dalam merespons perbedaan itu sendiri. Masyarakat Muslim pun terbelah dan semakin jauh dari pengamalan nilainilai Islam dan nilai-nilai demokrasi secara substantif.]

\section{Daftar Pustaka}

Adela, Fernanda Putra. 2012. "Proses Rekrutmen Politik Calon Legislatif Lokal di Medan pada Pemilu 2009: Studi Kasus Partai Keadilan Sejahtera." Perspektif5(April):1-11.

Agustina, Nur et. a. 2018. "Pengaruh Visi-Mis, Nilai Ideologi Partai, dan Figur terhadap Perilaku Pemilih dalam Pemilukada Kabupaten Buton tahun 2014." Neo Societal 3(3):526-33.

Algara, Carlos. 2019. "The Conditioning Role of Polarization in U.S. Senate Election Outcomes: A Direct-Election Era \& VoterLevel Analysis." Electoral Studies 59:1-16. 
Andriyani, Tereni, Sofia Zahra, dan Dian Daru Swasti. 2017. "Gambaran Pola Identifikasi Generasi Milenial dalam Memilih Tokoh Politik Melalui Media Sosial." Jurnal Ilmiah Penelitian Psikologi: Kajian Empiris \& NonEmpiris 3(2):69-81.

Ardianti, Raissa. 2018. "Framing Media terhadap Ulama di Balik Popularitas Jokowi dan Prabowo." Jurnal Transformative 4(2):4559.

Azmi, Khairul. 2014. "Perilaku Memilih Pemilih Pemula Masyarakat Kendal pada Pemilihan Umum Presiden dan Wakil Presiden Tahun 2014." FISIP Universitas Diponegoro.

Azra, Azyumardi. 2013. "Islamisasi Jawa." Studia Islamika 20(1):169-77.

Beg, Mirza Asmer. 2017. "The 2014 Parliamentary Elections in India: A Study of the Voting Preferences of Muslims in Uttar Pradesh." Round Table 106(5):567-76.

Bone, Hugh Alvin dan Austin Ranney. 1981. Politics and Voters. New York: McGrawHill.

Buskens, Vincent. 2015. "Rational Choice Theory in Sociology." hlm. 901-6 dalam International Encyclopedia of the Social \& Behavioral Sciences: Second Edition. Elsevier Inc.

Cesur, Resul dan Naci Mocan. 2018. "Education, Religion, and Voter Preference in a Muslim Country." Journal of Population Economics 31(1):1-44.

Fadli, Muhammad, Muh. Kausar Bailusy, Jayadi Nas, dan Achmad Zulfikar. 2015. "Keterlibatan Elit Lokal dalam Peningkatan Partisipasi Politik pada Pemilihan Bupati dan Wakil Bupati Kabupaten Toraja
Utara." Aristo: Jurnal Sosial, Politik, Humaniora 6(2):301-28.

Ganzach, Yoav. 2018. "Intelligence and the Rationality of Political Preferences." Intelligence 69:59-70.

Haboddin, Muhtar. 2012. "Menguatnya Politik Identitas di Ranah Lokal." Journal of Government and Politics 3(1):109-26.

Hafiz, Subhan. 2016. Teori Pilihan Rasional. Jakarta: Universitas Muhammadiyah Prof. Dr. Hamka.

Hamidi. 2010. "Komunikasi Politik dan Perilaku Pemimpin." Jurnal Salam 13(1):181-192.

Heath, Oliver, Gilles Verniers, dan Sanjay Kumar. 2015. "Do Muslim Voters Prefer Muslim Candidates? Co-Religiosity and Voting Behaviour in India." Electoral Studies 38:1018.

Hendryadi. 2014. "Kepemimpinan Karismatik." TeoriOnline Personal Paper.

Hong, Sounman dan Daniel Nadler. 2012. "Which Candidates Do the Public Discuss Online in an Election Campaign?: The Use of Social Media by 2012 Presidential Candidates and its Impact on Candidate Salience." Government Information Quarterly 29(4):455-61.

Howard, Philip N. 2005. “Deep Democracy, Thin Citizenship: The Impact of Digital Media in Political Campaign Strategy." The Annals of the American Academy of Political and Social Science 597(1):153-70.

Jones, David R. 2015. "Declining Trust in Congress: Effects of Polarization and Consequences for Democracy." The Forum 13(3):375-94.

Juditha, Christiany dan Josep J. Darmawan. 2018. "Use of Digital Media and Political Parti- 
cipation Milenial Generation." Jurnal Penelitian Komunikasi dan Opini Publik 22(2):91-105.

Kinari, Yusuke, Fumio Ohtake, Miles Kimball, Shoko Morimoto, dan Yoshiro Tsutsui. 2019. "Happiness Before and After an Election: An Analysis Based on a Daily Survey Around Japan's 2009 Election." Japan and the World Economy 49:187-94.

Kurzman, Charles dan Ijlal Naqvi. 2010. "Do Muslims Vote Islamic?" Journal of Democracy 21(2):50-63.

Liebhart, Karin dan Petra Bernhardt. 2017. "Political Storytelling on Instagram: Key Aspects of Alexander Van Der Bellen's Successful 2016 Presidential Election Campaign." Media and Communication 5(4):15-25.

Mohtar, A. 2005. "Pembangunan Kepimpinan dalam Organisasi." Jurnal Pengurusan Awam.

Monroe, Kristen Renwick. 2001. "Paradigm Shift: From Rational Choice to Perspective." International Political Science Review 22(2):151-72.

Nielsen, Kenneth Bo. 2011. "In Search of Development: Muslims and Electoral Politics in an Indian State." hlm. 345-70 dalam Forum for Development Studies. Vol. 38.

Ocampo, Angela X., Karam Dana, dan Matt A. Barreto. 2018. "The American Muslim Voter: Community Belonging and Political Participation." Social Science Research 72:84-99.

Oppenheimer, Joe A. 2008. Rational Choice Theory. London.
Rudatyo. 2009. "Kewenangan Mahkamah Konstitusi dalam Menangani Sengketa Pemilu." Jurnal Konstitusi 2(1):8-20.

Rußmann, Uta. 2012. “Online Political Discourse on Facebook: An Analysis of Political Campaign Communication in Austria." Zeitschrift für Politikberatung 5(3):115-25.

Sasmita, Jumiati dan Said As'ad Raihan. 2014. "Kepemimpinan Pria dan Wanita." Proceeding of the 6Th Ncfb and Doctoral Colloquium.

Sholikin, Ahmad. 2018. "Perbedaan Sikap Politik Elektoral Muhammadiyah Antara Pusat dan Daerah." Jurnal Polinter: Kajian Politik dan Hubungan Internasional 3(2):1-22.

Steiner, Jurg. 1990. "Rational Choice Theories and Politics: A Research Agenda and a Moral Question." PS: Political Science and Politics 23(1):46.

Suardi, Suardi. 2017. "Mencermati Pilihan Rakyat Antara Popularitas dalam Integritas Semu." Jurnal Dakwah Risalah 28(2):69.

van der Voort, H. G., A. J. Klievink, M. Arnaboldi, dan A. J. Meijer. 2018. "Rationality and Politics of Algorithms. Will the Promise of Big Data Survive the Dynamics of Public Decision Making?" Government Information Quarterly 36(1):27-38.

Yoelvan Negong, Yohanes. 2018. "Politik Identitas dalam Pemilihan Gubernur Nusa Tenggara Timur 2013 di Kota Kupang." Politika: Jurnal Ilmu Politik 8(2):52-63. 